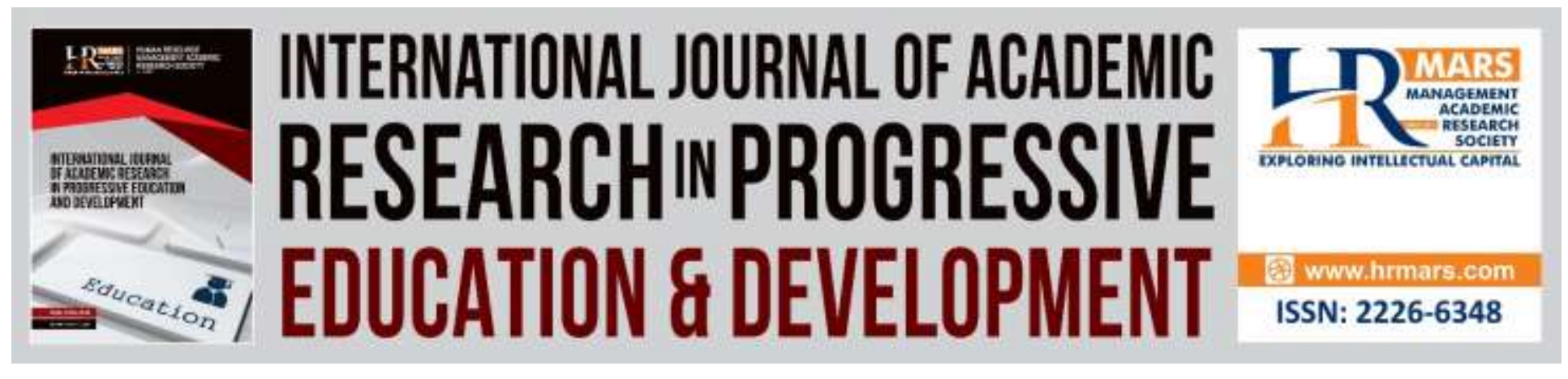

\title{
The Influence of Higher Order Thinking and Metacognitive Skills towards Hands-On Teaching among Primary School Science Teachers
}

Tajularipin Sulaiman, Punnithann Subramaniam, Nurzatulshima Kamarudin

To Link this Article: http://dx.doi.org/10.6007/IJARPED/v8-i4/6497

DOI:10.6007/IJARPED/v8-i4/6497

Received: 15 August 2019, Revised: 14 September 2019, Accepted: 03 October 2019

Published Online: 20 October 2019

In-Text Citation: (Sulaiman, Subramaniam, \& Kamarudin, 2019)

To Cite this Article: Sulaiman, T., Subramaniam, P., \& Kamarudin, N. (2019). The Influence of Higher Order Thinking and Metacognitive Skills towards Hands-On Teaching among Primary School Science Teachers. International Journal of Academic Research in Progressive Education and Development, 8(4), 245-258.

Copyright: (C) 2019 The Author(s)

Published by Human Resource Management Academic Research Society (www.hrmars.com)

This article is published under the Creative Commons Attribution (CC BY 4.0) license. Anyone may reproduce, distribute, translate and create derivative works of this article (for both commercial and non-commercial purposes), subject to full attribution to the original publication and authors. The full terms of this license may be seen at: http://creativecommons.org/licences/by/4.0/legalcode

Vol. 8(4) 2019, Pg. 245-258

http://hrmars.com/index.php/pages/detail/IJARPED

JOURNAL HOMEPAGE

Full Terms \& Conditions of access and use can be found at http://hrmars.com/index.php/pages/detail/publication-ethics 


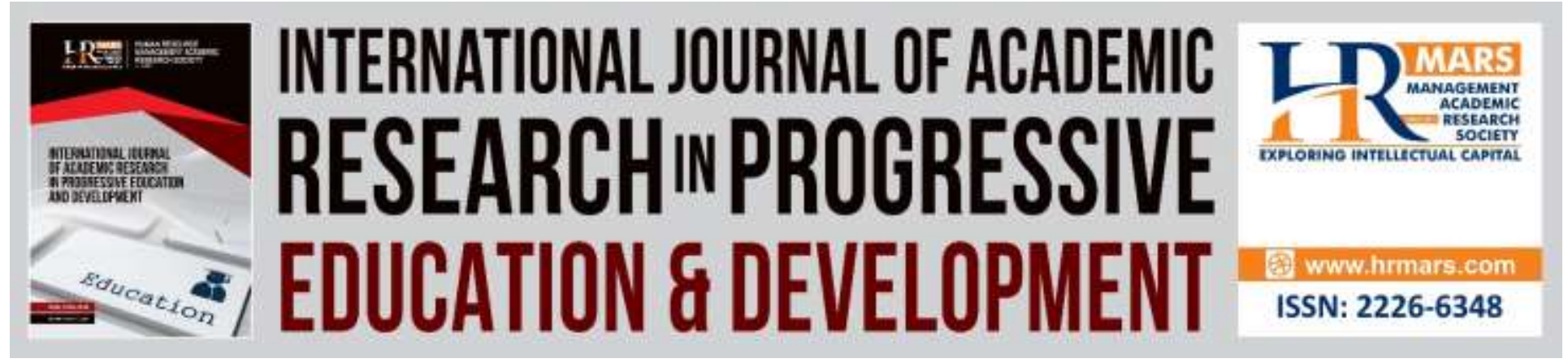

\title{
The Influence of Higher Order Thinking and Metacognitive Skills towards Hands-On Teaching among Primary School Science Teachers
}

\author{
Tajularipin Sulaiman, Punnithann Subramaniam,Nurzatulshima \\ Kamarudin
}

Faculty of Educational Studies, University Putra Malaysia

\begin{abstract}
Higher order thinking skills and metacognitive skills are essential skills in acquiring knowledge in today's challenging world. This study examined the influence of higher order thinking and metacognitive skills on hands-on teaching in science among primary school Science teachers. The first objective of this study is to determine the level of higher order thinking and metacognitive skills among science teachers. The second is to examine the relationship between higher order thinking and metacognitive skills on hands-on teaching in science. The study used descriptive and correlation design. The findings of the descriptive analysis showed that the level of higher order thinking skills is high ( $M=4.36$, S.D. $=0.577$ ) among science teachers. In addition, the findings show that metacognitive skill level was also high $(M=4.39$, S.D. $=0.579)$. Next, the level of handson teaching in science is high ( $M=4.37$, S.D. $=0.543)$ among the science teachers. The findings show that there is a significant relationship between higher order thinking skills and hands-on teaching in science $(r=0.739, n=94, p<0.01)$. Besides, there is a significant relationship between metacognitive skills and hands-on teaching in science $(r=0.826, n=94, p<0.01)$. There was a stronger relationship between metacognitive skills to hands-on teaching than higher order thinking skills. Multiple regression analysis was conducted to observe the influence and the findings showed that the Beta value for metacognitive skills is higher (0.626) compared to the Beta value of higher order thinking skills (0.265). This indicates that metacognitive skills have more influence on hands-on teaching among the primary school science teachers. This study suggests that science teachers need to focus more on higher order thinking skills (HOTS) and metacognitive teaching.
\end{abstract}

Keywords: Higher Order Thinking Skills, Metacognition, Science, Hands-on Teaching

\section{Introduction}

The progress of a country is dependent on the mastery of skills and learning by its citizens. With an ineffective education system, a country will be left behind. The education system is a medium responsible for the transmission of knowledge and skills to individuals. Higher order thinking skills 
(HOTS) are the abilities to apply knowledge, skills and values. According to the National Education Philosophy in line with the Malaysian Education Blueprint (MEB), thinking skills are part of the six aspirations that must be acquired by every student in order for the country to be competitive at a global stage (MEB 2013-2025). Thinking skills are crucial, should be practised in the classroom, and are the keys to a student's success (Nessel \& Graham, 2007).

Furthermore, our country is striving to be on par with developed countries and therefore, it is incumbent on our education system produce knowledgeable students. The Malaysian people should also be able to think creatively and critically as well as be able to communicate effectively on an international level. Our government is committed to the belief that the application of Higher Order Thinking Skills (HOTS) in the teaching and learning that can improve the performance of a country. Metacognitive skills come from the theory forwarded by Flavell (1979) emphasizing the "thinking about thinking"or better understood as one's awareness about the thinking process. Instruction using this strategy may bring about the tendency to think more among students (Hacker, Dunlosky, Graesser, 2011). The design of metacognitive activities focuses on the cognitive and social development of a student that can challenge their thinking from theoretical and practical standpoints (Lee, 2009).

Higher order thinking and metacognitive skills are important for the production of students capable of competing intellectually in the face of challenges in knowledge acquisition in the future. Our government will be competing internationally especially in the Programme for International Student Assessment (PISA) and Trends in International Mathematics and Science Study (TIMSS) assessments stated in the Malaysian Education Blueprint 2013-2025. The two related terms mentioned above, higher order thinking and metacognitive skills, can be applied in hands-on teaching. A student's learning becomes effective when it is active and they are involved in hands-on activities (Abruscato \& DeRossa, 2010).

\section{Literature Review}

Malaysia underperformed in the study by the International Association for The Evaluation of Educational Achievement (IEA) for the UN Education Index (MOE, 2014). The study placed Malaysia at 98 out of 181 countries. The Programme for International Student Assessment (PISA) measures the literacy rate of students aged 15 years, particularly in Mathematics, Science, and their reading rate. The Trends in International Mathematics and Science Study (TIMSS) measures proficiency levels among international students in Mathematics and Science. The findings of the TIMSS and PISA studiesindicate a performance downturn in Science at the lower secondary school level (MOE, 2014) as shown in Tables 1 and 2. 
INTERNATIONAL JOURNAL OF ACADEMIC RESEARCH IN PROGRESSIVE EDUCATION AND

DEVELOPMENT

Vol. 8, No. 4, 2019, E-ISSN: 2226-6348 @ 2019 HRMARS

Table 1

Malaysia ranking for the Science subject in the TIMSS study from 1999 to 2011

Trends in International Mathematics and Science Study (TIMSS) Committee for the Science subject

\begin{tabular}{lll}
\hline Year & Rank & Average Score \\
\hline 1999 & 22 out of 38 & 492 \\
2003 & 20 out of 45 & 510 \\
2007 & 21 out of 49 & 471 \\
2011 & 32 out of 42 & 426 \\
\hline
\end{tabular}

(Source: MOE, 2014)

Table 2

Malaysia ranking for the Science subject in the PISA study from 2009 and 2012

Programme for International Student Assessment (PISA) for the Science subject

\begin{tabular}{lll}
\hline Year & Rank & Average Score \\
\hline 2009 & 52 out of 74 & 422 \\
2012 & 53 out of 65 & 420 \\
\hline
\end{tabular}

(Source: MOE, 2014)

Based on Table 1, it is evident that Malaysia's ranking in the TIMSS study fell from 1999 to 2011. In 1999, we placed at 22 out of 38 countries and scored an average of 492 for the Science subject in the TIMSS study, whereas in 2011, we placed at 32 out of 42 and scored an average of 426. The TIMSS findings recorded a decline in ranking and average score in the Science subject by our country. On the other hand, Table 2 which shows the results of the PISA study for the Science subject also recorded a decline. In 2009, our country ranked 52 out of 74 countries and scored an average of 422, while in 2012, we ranked 53 out of 65 countries and scored an average of 420.

Nevertheless, student performance differed between the TIMSS and PISA studies in the Penilaian Menengah Rendah (PMR) lower secondary assessment. The TIMSS and PISA studies also found a decrease in performance for Science yet the PMR (2011) examination results showed an increase in the number of ' $A$ ' grades in the Science subject as seen in Table 3.

Table 3

Percentage of students achieving 'A' for the Science subject in the PMR 2011 examination PMR examination for the Science subject

\begin{tabular}{ll}
\hline Year & Percentage of students achieving 'A' (\%) \\
\hline 2010 & 18.5 \\
2011 & 21.7 \\
\hline
\end{tabular}

(Source: MOE, 2014)

This discrepancy occurs due to students prioritising the method of memorizing facts and is not proficient in answering problem-solving questions (Shih Ting Lee, 2009 \& Mohd Ali, 2014). However, TIMSS and PISA contain different high cognitive level questions. The statistics above 
clearly show that the Science education in our country is deteriorating, warranting a study of its root cause. In conclusion, both assessments proved that our students have yet to acquire higher order thinking skills and metacognitive skills.

Additionally, the drop in number of science stream students today is becoming a concern as many students are inclined to choose the Arts stream as it is easier to excel in the SPM examination (MOE, 2014). Until 2012, the percentage of student entry into the science stream never attained $60 \%$ but instead, experienced a disquieting shrinkage (MOE, 2013). In the Report on Strategies to Achieve the 60:40 Science:Arts Stream Policy, analysis by MOE (2014) indicated the percentage of students in Science and Technology streams diminished from 2006 to 2012. In 2011, the percentage of Science stream students at the secondary level was at 44.01 percent compared to 46.43 percent in 2005.

Most school teachers still use traditional methods of instruction which are teacher-centred. The use and practice of effective teaching approaches such as the critical method, demonstration, and constructivism are uncommon among Science teachers in our country (Sulaiman \& Rahim, 2010). Moreover, a teacher does not only deliver knowledge and explanation about Science; they are fully responsible for ensuring the student enjoys learning. Most science teachers are unable to enhance students' higher order thinking skills as the teachers practise traditional teaching methods (Budiman, 2008). Students who merely memorize scientific facts and concepts will not have their thinking stimulated (Synder \& Synder, 2008). Revell and Wainright (2009) explains that traditional instruction methods can cause drastic decline in a student's concentration levels after the first 20 minutes. Active learning methods are more vital in improving students' cognitive and communication skills than traditional teaching methods (Exley \& Dennick, 2004). It is apparent that students should be given the opportunity to understand scientific concepts through handson or minds-on activities. To conclude, active teaching methods are more essential and should be practised by all educators as this methods focuses on the active involvement of the student in the process of obtaining knowledge.

Primary school Science teachers in rural areas incorporated less of the development of higher order thinking skills during teaching and learning activities due to time constraints (Lee, 2009). The lack in application of higher order thinking skills causes students to fail to acquire in-depth understanding of scientific concepts and leads to rote memorization (Yun, 2012). In the study by Yun (2012), primary school Science teachers in a rural area in Sarawak applied less of higher order thinking skills due to time constraints and they solely taught according to the syllabus to prepare students for examination, namely UPSR for primary schools. Latest research from Nachiappan et al. (2019) reported that, the implementation of HOTS at preschool level is still at a moderate level as there are still less skilled teachers in implementing HOTS during the teaching and learninf process. Nonetheless, this study will examine the application of higher order thinking skills among rural school teachers.

A study by Lee (2009) found that, for science teachers who emphasized less on higher order thinking skills in the classroom especially critical learning, their students did not score well in 
Vol. 8, No. 4, 2019, E-ISSN: 2226-6348 @ 2019 HRMARS

science examinations. Meanwhile, teachers who do apply higher order thinking skills produced higher marks. It is unmistakable that the application of HOTS in hands-on teaching can enhance students' reasoning and creativity.

Besides that, higher order thinking skills are important in hands-on teaching. According to Ibrahim \& Husain (2014), students who do not take part in hands-on activities are unable to answer questions that require prediction and the formulation of hypothesis as they are not asked higher order questions that stimulate their thinking. It becomes clear that HOTS and hands-on teaching positively impacts a student's academic advancement.

Metacognitive skills are likewise key in hands-on teaching and bring a corresponding positive impact on students. Research by Ghafar and Ibrahim (2011) found that metacognitive skills are fundamental in hands-on activities such as controlling variables and generating hypotheses. In this study, teachers who did not use metacognitive methods did not help students in listing all variables and creating hypotheses. The investigation was conducted in the form of a test and all Science Paper Two questions required students to recall experiment conditions, list the variables, and formulate a hypothesis. Based on the studies above, the value of higher order thinking skills and metacognitive skills among teachers becomes evident in raising student performance. However, these studies draw from teacher populations in varying areas and the respondent samples included trainee teachers. Teachers in this study operate in a distinct work environment and all respondents have served as teachers for more than 2 years. In addition, there are no studies on the correlation between higher order thinking skills and metacognitive skills with hands-on teaching.

Hence, this study was performed to explore the relationship between higher order thinking skills and metacognitive skills with hands-on teaching among primary school Science teachers.

\section{Theoretical Framework}

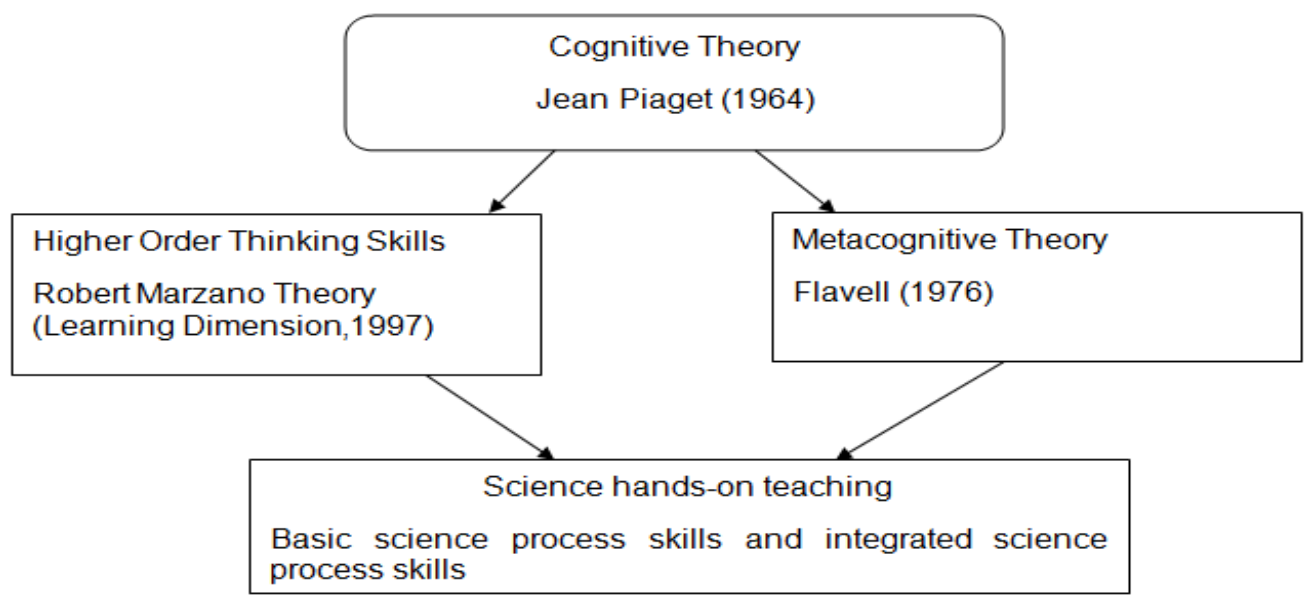

Figure 1. Relation of cognitive theory in Robert Marzano's theory and Flavell's theory 
Figure 1 shows the cognitive theory of Jean Piaget (1964) is the fundamental theory for this research. Under the cognitive of Jean Paiget (1964), Robert Marzano's theory in Learning Dimension (1997) higher order thinking skills are the main component. In Learning Dimension (1997), higher order thinking skills are very vital in encouraging pupils to learn and understand the abstract concepts of sciences. Besides, Flavell's theory of metacognitive mentioned about 3 components. There are reflecting, planning and evaluating. These components helps an individual to understand a concept more easily. Both theories help a student in understanding a concept during science hands-on teaching.

\section{Conceptual Framework}

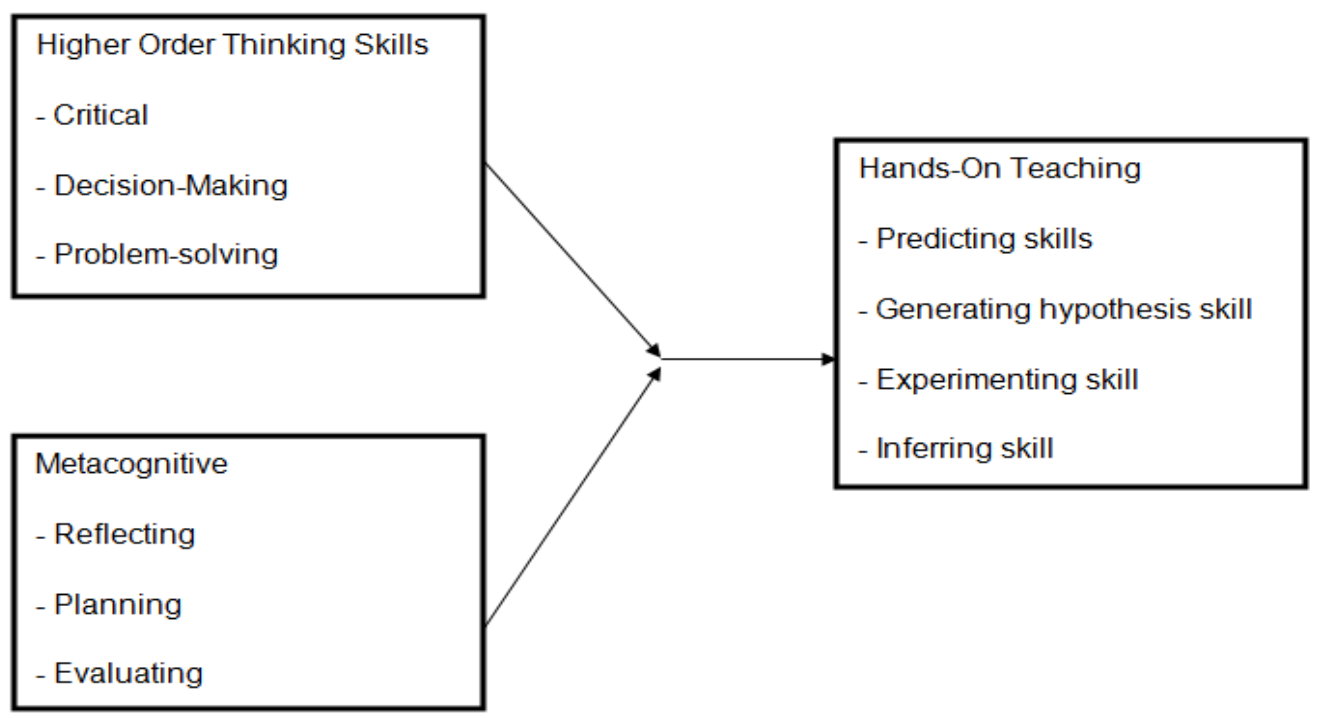

Figure 2. Relationship between higher order thinking skill subconstructs and metacognitive subcontructs towards science hands-on teaching subconstructs

Figure 2 shows the relationship between higher order thinking skills and metacognitive towards science hands-on teaching. Higher order thinking skills and metacognitive are the independent variables and the hands-on teaching is the dependent variables.

\section{Methodology}

This study used descriptive and correlation design. Correlation studies explicate the relationship of two or more variables (Ghazali \& Sufean, 2016; Pallant, 2013). In this study, the correlation method was used to investigate the relationship between higher order thinking skills and metacognitive skills with hands-on teaching among Science teachers. Correlation coefficient values were used to determine weak, intermediate, or strong association among these 3 constructs. This study utilizes a quantitative approach using survey and questionnaire.

The researchers adopted the simple random sampling technique to select the schools involved in this study. Through this sampling method, 36 schools were chosen. There are 3 constructs in 
Vol. 8, No. 4, 2019, E-ISSN: 2226-6348 @ 2019 HRMARS

this study instrument, namely HOTS, metacognitive skills and hands-on teaching. The researchers conducted a pilot study before performing the actual study. The Cronbach's alpha coefficient value of the pilot study was 0.967 . The researchers validated the questionnaire items which were reviewed by 3 Science subject experts.

\section{Results}

The findings show that 63 respondents (67.0\%) taught at rural primary schools while only 31 respondents (33.0\%) taught at urban primary schools. The findings show only 27 respondents $(28.7 \%)$ were male and the remaining 67 respondents $(71.3 \%)$ were female. The findings show that the respondents were multiracial with 50 respondents (53.2\%) being Malay, 19 respondents (20.2\%) of Chinese ethnicity and 25 respondent (26.6\%) of Indian ethnicity.

Table 4 below indicates that the level of higher order thinking skills in this study was high with a mean value of $M=4.36$ (S.D. $=0.577$ ). The Critical subconstruct recorded the highest mean value of $M=4.40$ (S.D. $=0.558$ ). This denotes that the respondents in this study practise critical thinking and is highly committed being analytical and curious to gain understanding and new knowledge. The Decision-making subconstruct recorded a mean value of $M=4.32$ (S.D. $=0.624$ ) and the Problem-solving subconstruct recorded a mean value of $M=4.35$ (S.D. $=0.620$ ).

Table 4

Analysis of the level of higher order thinking skills by subconstructs

\begin{tabular}{lcccc}
\hline $\begin{array}{c}\text { Higher Order Thinking Skills } \\
\text { Subconstruct }\end{array}$ & N & Mean & $\begin{array}{c}\text { Standard } \\
\text { Deviation }\end{array}$ & $\begin{array}{c}\text { Interpretation/L } \\
\text { evel }\end{array}$ \\
\hline Critical & 94 & 4.40 & 0.558 & High \\
Decision-making & 94 & 4.32 & 0.624 & High \\
Problem-solving & 94 & 4.35 & 0.620 & High \\
\hline Overall & $\mathbf{9 4}$ & $\mathbf{4 . 3 6}$ & $\mathbf{0 . 5 7 7}$ & High \\
\hline
\end{tabular}

Notes: Mean score range: 1.00-2.33 = Low, 2.34-3.67 = Intermediate, 3.68-5.00 = High

Table 5 below indicates that the level of metacognitive skills among primary school Science teachers in this study is high with an overall mean value of $M=4.39$ (S.D. $=0.579$ ). The Planning subconstruct recorded the highest mean value of $M=4.43$ (S.D. $=0.550$ ). This denotes that the respondents of this study practises planning in preparation before the execution of hands-on teaching. The Reflecting subconstruct recorded a mean value of $M=4.38$ (S.D. $=0.568$ ) and the Evaluating subconstruct recorded a mean value of $M=4.35$ (S.D. $=0.620$ ). 
INTERNATIONAL JOURNAL OF ACADEMIC RESEARCH IN PROGRESSIVE EDUCATION AND DEVELOPMENT

Vol. 8, No. 4, 2019, E-ISSN: 2226-6348 @ 2019 HRMARS

Table 5

Analysis of the level of metacognitive skills by subconstructs

\begin{tabular}{lcccc}
\hline Metacognitive Subconstruct & $\mathbf{N}$ & Mean & $\begin{array}{c}\text { Standard } \\
\text { Deviation }\end{array}$ & $\begin{array}{c}\text { Interpretation/L } \\
\text { evel }\end{array}$ \\
\hline Reflecting & 94 & 4.38 & 0.568 & High \\
Planning & 94 & 4.43 & 0.550 & High \\
Evaluating & 94 & 4.35 & 0.620 & High \\
\hline Overall & $\mathbf{9 4}$ & $\mathbf{4 . 3 9}$ & $\mathbf{0 . 5 7 9}$ & High \\
\hline
\end{tabular}

Notes: Mean score range: 1.00-2.33 = Low, 2.34-3.67 = Intermediate, 3.68-5.00 = High

Table 6 below indicates the level of hands-on teaching according to science process skills. The findings of this study show that the respondents are highly skilled in Generating Hypothesis which records the highest mean value of $M=4.38$ (S.D. $=0.542$ ). This denotes that Science teachers in this area are capable of imparting the hypothesis generation skill through the execution of handson teaching. The findings show that Predicting skill recorded the second highest mean value of $M=4.37$ (S.D. $=0.566)$, followed by Experimenting skill $(M=4.36$, S.D. $=0.566)$ and Inferring skill $(\mathrm{M}=4.35$, S.D. $=0.499)$.

Table 6

Analysis of the level of hands-on teaching by subconstructs

\begin{tabular}{l|c|c|c|c}
\hline \multicolumn{1}{c|}{$\begin{array}{c}\text { Hands-On Teaching } \\
\text { Subconstruct }\end{array}$} & $\mathbf{N}$ & Mean & $\begin{array}{c}\text { Standard } \\
\text { Deviation }\end{array}$ & $\begin{array}{c}\text { Interpretation/L } \\
\text { evel }\end{array}$ \\
\hline Predicting skill & 94 & 4.37 & 0.566 & High \\
Generating hypothesis skill & 94 & 4.38 & 0.542 & High \\
Experimenting skill & 94 & 4.36 & 0.566 & High \\
Inferring skill & 94 & 4.35 & 0.499 & High \\
\hline Overall & $\mathbf{9 4}$ & $\mathbf{4 . 3 7}$ & $\mathbf{0 . 5 4 3}$ & High \\
\hline
\end{tabular}

Notes: Mean score range: 1.00-2.33 = Low, 2.34-3.67 = Intermediate, 3.68-5.00 = High

Furthermore, analysis of the research findings show a significant relationship between higher order thinking skills and hands-on teaching $(r=0.739, n=94, p<0.01)$. Table 7 below indicates that the more skilled the teacher in higher order thinking, the more the teacher would practise hands-on teaching. 
INTERNATIONAL JOURNAL OF ACADEMIC RESEARCH IN PROGRESSIVE EDUCATION AND DEVELOPMENT

Vol. 8, No. 4, 2019, E-ISSN: 2226-6348 @ 2019 HRMARS

Table 7

Correlation between higher order thinking skill subconstructs and overall hands-on teaching

\begin{tabular}{lccc}
\hline $\begin{array}{c}\text { Higher Order Thinking } \\
\text { Skills Subconstruct }\end{array}$ & $\begin{array}{c}\text { Pearson Correlation } \\
(\mathbf{r})\end{array}$ & $\begin{array}{c}\text { Overall Hands-On } \\
\text { Teaching }\end{array}$ & $\begin{array}{c}\text { Level of } \\
\text { Correlation }\end{array}$ \\
\hline Critical & $r$ & $0.500^{* *}$ & Strong \\
Decision-making & $p$ & 0.000 & \\
& $r$ & $0.633^{* *}$ & Strong \\
Problem-solving & $p$ & 0.000 & \\
& $r$ & $0.804^{* *}$ & Strong \\
\hline Overall Higher Order & $p$ & 0.000 & \\
Thinking Skills & $r$ & $0.739^{* *}$ & Strong \\
\hline
\end{tabular}

Notes: $\mathrm{r}: 0.10-0.29=$ Weak correlation

0.30-0.49 = Intermediate correlation

0.50-1.00 = Strong correlation

Notes: ${ }^{* *}$ Significant at $p<0.01$

Analysis of the research findings also shows a significant relationship between metacognitive skills and hands-on teaching $(r=0.826, n=94, p<0.01)$. Table 8 indicates that the higher the metacognitive skills of the teacher, the more the teacher would practise hands-on teaching.

Table 8

Correlation between metacognitive subconstructs and overall hands-on teaching

\begin{tabular}{lccc}
\hline $\begin{array}{c}\text { Metacognitive } \\
\text { Subconstruct }\end{array}$ & $\begin{array}{c}\text { Pearson Correlation } \\
(\mathbf{r})\end{array}$ & $\begin{array}{c}\text { Overall Hands-On } \\
\text { Teaching }\end{array}$ & $\begin{array}{c}\text { Level of } \\
\text { Correlation }\end{array}$ \\
\hline Reflecting & $r$ & $0.773^{* *}$ & Strong \\
& $p$ & 0.000 & \\
Planning & $r$ & $0.643^{* *}$ & Strong \\
& $p$ & 0.000 & \\
Evaluating & $r$ & $0.717^{* *}$ & Strong \\
& $p$ & 0.000 & \\
\hline Overall Metacognitive & $r$ & $0.826^{* *}$ & Strong \\
Skills & $p$ & 0.000 & \\
\hline
\end{tabular}

Notes: $\mathrm{r}: 0.10-0.29=$ Weak correlation

0.30-0.49 = Intermediate correlation

$0.50-1.00=$ Strong correlation

Notes: ${ }^{* *}$ Significant at $p<0.01$

In conclusion, the findings show a significant relationship between higher order thinking and metacognitive skills with hands-on teaching. The researchers reject both null hypotheses with evidence that there is significant relationship between higher order thinking and metacognitive skills with hands-on teaching among science teachers. The $r$ value for metacognitive skills is $r=$ 0.826 and the $r$ value for higher order thinking skills is $r=0.739$. Both hypotheses also have high 
Vol. 8, No. 4, 2019, E-ISSN: $2226-6348$ @ 2019 HRMARS

correlation levels. The correlation between metacognitive skills and hands-on teaching is stronger than higher order thinking skills.

Table 9 indicates the regression analysis of various higher order thinking skills and metacognitive skills in hands-on teaching. Findings show that the Beta value for the metacognitive variable is higher at 0.626 than the Beta value of higher order thinking at 0.265 . Findings apparently show that metacognitive skills is the independent variable that has stronger influence on hands-on teaching among Science teachers.

Table 9

Regression analysis of higher order thinking and metacognitive skills in hands-on teaching

\begin{tabular}{lccc}
\hline \multicolumn{1}{c}{ Variable } & Beta & t & $\boldsymbol{p}$ \\
\hline Higher order thinking skills & 0.265 & 3.083 & 0.003 \\
Metacognitive skills & 0.626 & 7.277 & 0.000 \\
\hline
\end{tabular}

$\mathrm{R}=0.844 \quad \mathrm{~F}=113.060 \quad$ Adjusted $R^{2}=0.707$

Table 9 also indicates the Adjusted $R^{2}$ value of 0.707 . Findings show this value converted into percentage at 71 percent. It denotes that the independent variables higher order thinking skills and metacognitive skills accounts of 71 percent of hands-on teaching while 29 percent comprises other independent variables that have yet to be identified.

\section{Discussion}

Analysis of findings in this research shows that the level of higher order thinking skills, overall or by subcontructs, is high. This denotes that science teachers have high tendency towards higher order thinking skills. Teachers highly skilled in higher order thinking will, as a matter of course, use higher order thinking in hands-on teaching. They are inclined to use critical properties such as curiosity, analytical thinking, decision-making and problem- solving during hands-on teaching.

The findings of this study show that teachers' metacognitive skill levels, overall or by subconstruct, are high. This shows that science teachers are highly capable in metacognitive skills. Science teachers with high metacognitive skills will naturally utilize the skills during handson teaching. They are inclined to apply the skills of reflecting, planning, and evaluating in their hands-on teaching. In general, the level of metacognitive skills among Science teachers are the highest $(M=4.39$, S.D. $=0.579)$ followed by the level of higher order thinking skills $(M=4.36$, S.D. $=0.577)$.

In this study, hands-on teaching executed only involved the skills of reflecting, inferring, generating hypothesis, and experimenting. The hands-on teaching constructed involved 4 subconstructs, namely the skills of predicting, inferring, generating hypothesis, and experimenting. Analysis of the findings show that there is a high level of hands-on teaching, overall or by subconstructs. 
Correlation analysis of this study shows a significant relationship between the subconstructs of higher order thinking skills and hands-on teaching. This correlation is strong and explains that the more skilled the teacher in higher order thinking, the more the teacher practises hands-on teaching. This shows that Science teachers who apply higher order thinking skills tend to use instruction based on curiosity in hands-on teaching.

Correlation analysis of this study shows a significant relationship between the subconstructs of metacognitive skills and hands-on teaching. This correlation is strong and explains that the higher the metacognitive skills of a teacher, the more the likely the teacher will practise hands-on teaching. This shows that Science teachers that practise metacognitive skills tend to plan strategies and arrange the time to achieve the objective of a lesson during hands-on teaching.

Regression analysis of this study shows that the Beta value of the metacognitive variable is greater than the Beta value of higher order thinking skills. The findings make it evident that metacognitive skills is the independent variable that determines hands-on teaching among Science teachers. It also shows that science teachers practise reflecting, planning, and evaluating.

\section{Conclusion}

A teacher's efficiency and excellence in executing teaching and learning strategies will be the measuring stick of a country's future progress. The Science curriculum and the MEB (2013-2025) places great emphasis on students' proficiency in higher order thinking. Therefore, higher order thinking skills and metacognitive skills should be instilled in every student in order to produce the human capital that can contribute to the country in the challenging era of globalisation in the future.

To embrace higher order thinking skills and metacognitive thinking skills is not easy because before the desired attainment is obtained, practice must be established first. Practice will be formed if repeatedly and consistently repeated by a teacher.

The effort to cultivate higher order thinking and metacognitive skills face is arduous as it requires the application of various skills such as critical thinking, decision-making, problem-solving, reflecting, planning, and evaluating. Consequently, the researchers are of the opinion that there is a necessity to increase and reinforce the quality of teachers, especially in the above-mentioned skills in order to accomplish effective hands-on teaching. An educator should stimulate students' thinking by applying higher order thinking skills and metacognitive skills when teaching.

Student-centred learning is crucial and one of the means towards that end is hands-on teaching. Hands-on teaching is one of the methods that actively involves the student during the teaching process. Higher order thinking skill and metacognitive skills can help to enhance a student's understanding of scientific concepts, decision-making, and problem-solving during hands-on teaching. 
Vol. 8, No. 4, 2019, E-ISSN: 2226-6348 C 2019 HRMARS

The researchers hope that this study can open the eyes and minds of teachers to the importance of higher order thinking skills and metacognitive skills in hands-on teaching in order to promote a culture of practising higher order thinking among students as well as among the teachers themselves.

\section{Corresponding Author}

Tajularipin Sulaiman is associate professor at the Faculty of Educational Studies, Universiti Putra Malaysia, 43400 UPM Serdang, Selangor Darul Ehsan, Malaysia. E-mail: tajulas@upm.edu.my

\section{References}

Abruscato, J., \& DeRossa, D. A. (2010). Teaching children Science: A discovery approach. (7th edition). Boston: Allyn \& Bacon.

Yun, C. J. (2012). Kesan Penggunaan Kaedah "Hands-On” dalam Proses Pembelajaran Sains Tahun 3. Seminar Penyelidikan Tindakan IPG KBL Tahun 2012 (pp. 165-179).

Exley, K., \& Dennick, R. (2004). Giving a lecture: From presenting to teaching. London: Routledge Falmer.

Darusalam, G., \& Hussin, S. (2016). Metodologi penyelidikan dalam pendidikan: Amalan dan analisis kajian. Kuala Lumpur: Universiti Malaya.

Hacker, D. J., Dunlosky, J., \& Graesser, A. C. (1998). The educational psychology series. Metacognition in educational theory and practice. US: Lawrence Erlbaum Associates Publishers.

Malaysia Ministry of Education. (2013). Malaysian Education BluePrint (2013-2015). Ministry of Education: Kuala Lumpur.

Malaysia Ministry of Education. (2014). Higher Order Thinking Skilss. Ministry of Education: Kuala Lumpur.

Malaysia Ministry of Education. (2014). Third International Research on Science and Mathematics. Ministry of Education: Kuala Lumpur.

Ibrahim, M. A., \& Husain, R. (2014). Mastery of Observation Skill and Predicting Skill in Science among Standard Five students in Johor Bharu District. Education Journal Faculty Of Education University Teknologi Malaysia, 15(3), 35-42.

Nachiappan, S., Osman, R., Masnan, A. H., Mustafa, M. C., Hussein, H., \& Suffian, S. (2019). The Development Of Preschools' Higher Order Thinking Skills (HOTs) Teaching Model towards Improving the Quality of Teaching. International Journal of Academic Research in Progressive Education and Development, 8(2), 39-53.

Ghafar, N., Ibrahim, A. R. (2011). Evaluation of Relationship Between Level of Science Concept and Level of Science Process Skills of Teacher. Journal Of Science And Mathematics Educational, 3(2011), 1-19.

Nessel, D. D., \& Graham, J. M. (2007). Thinking Strategies for student achievement: improving learning a cross the curriculum, $K-12$. $\left(2^{\text {nd }} e d.\right)$. Thousand oaks, Carlifonia: Corwin Press. A SAGE Publication Company.

Pallant, J. (2013). SPSS survival manual: A stepby step guide to data analysis using SPSS (5th ed.). England: McGraw Hill. 
Revell, A. \& Wainwright, E. (2009). What Makes Lectures "Unmissable"? Insights into Teaching Excellence and Active Learning. Journal of Geography in Higher Education, 33(2), 209-223.

Shih Ting Lee. (2009). Examining the Relationships between Metacognition, Selfregulation and Critical Thinking in Online Socratic Seminars for HighSchool Social Studies Students. The University of Texas at Austin. Doctoral Dissertation.

Synder, L.G., \& Synder, M. J. (2008). Teaching Critical Thinking and Problem Solving Skills. The Delta Phi Epsilon Journal, L(2), 90-99.

Tajularipin Sulaiman \& Nor Azlina Abdul Rahim. (2010). Various effective approaches in science teaching. Universiti Putra Malaysia: Publication of University Putra Malaysia.

Zainol Badli Budiman. (2008). Development of Cognitive Conflict Module and its effect on Cognitive Development and Science Achievement. National University of Malaysia. Doctoral Dissertation. 